\title{
Getting Order Out of Chaos: A Mathematical Model of Political Conflict
}

\author{
Georg P. Mueller \\ $\mathrm{PhD}$, Faculty of Economics and Social Sciences, University of Fribourg \\ Address: Blvd de Pérolles 9o, CH-17oo Fribourg, Switzerland \\ E-mail: georg.mueller_unifr@bluewin.ch
}

\begin{abstract}
Time series data about violent internal conflicts such as protests or riots often display irregular fluctuations. This article argues that these fluctuations are manifestations of a deterministic chaos that can be described by a relatively simple difference equation. It presents a mathematical contagion model of the interaction between three groups: (a) already mobilized rebellious citizens, who are protesting against the government and its policies, (b) initially non-rebellious but frustrated groups, which become mobilized by imitating the rebels, and (c) repressive governmental forces, which attempt to curb the rebellion and reduce the number of mobilized persons. The integration of these three processes results in a logistic growth model, which converges for many parameter configurations to stable shares of mobilized protesters, including in certain situations also zero-protest. However, for other specific parameters this logistic process may result in chaotic fluctuations in protest actions, which are dangerous to the regime as they are unpredictable and often very massive. By computer-simulations, the article explores the consequences of the different parameter configurations for protest $\mathrm{dy}$ namics. In order to ensure their political survival, most governments have a vital interest in getting from chaotic conflict dynamics to a stable equilibrium of protest, preferably at the level of zero. They may actively do so (i) by reforms which reduce the share of frustrated citizens who can be mobilized for protest (ii) by the intimidation and/or repression of protesters, (iii) by censoring media reports about protests such that the conflicts become less contagious. A formal analysis of the model shows that the most successful of the three strategies are reforms, which reduce the share of frustrated citizens and thus lead to a new political order.
\end{abstract}

Keywords: social contagion, political conflict, reforms, chaos theory, mathematical models, computer simulation.

\section{Introduction and Overview}

Time-series of political protest events often look chaotic with many irregular up- and downswings. Fig. 1 presents data from the US as an illustration of this kind of conflictdynamics, which are similar to graphs in textbooks about logistic chaos (see e.g. Brown, 1995: 15). Given the fruitfulness of chaos-models for social sciences (see e.g. Kiel, Elliott, 1996; Creedy, Martin, 1994a; Eve, Horsfall, Lee, 1997; Bühl, 1990: chap. 5) the author looked for a formal model of protests, which is sociologically plausible and displays chaotic dynamics. Unable to find an appropriate model in the existing literature, he developed a contagion model of the interaction between three groups: (a) already mobilized rebellious citizens, who are protesting against the government and its policies,

(c) Georg P. Mueller, 2017

(c) Centre for Fundamental Sociology, 2017

DOI: $10.17323 / 1728-192 X-2017-4-37-52$ 
(b) initially non-rebellious but frustrated groups, which become mobilized by imitating the rebels, and (c) repressive governmental forces, which attempt to curb the rebellion and reduce the number of mobilized persons. The integration of these three processes resulted in a logistic growth model, which has three central parameters: the share of the frustrated citizens in the total population, the contagion rate of protest, and the repressiveness of the government.

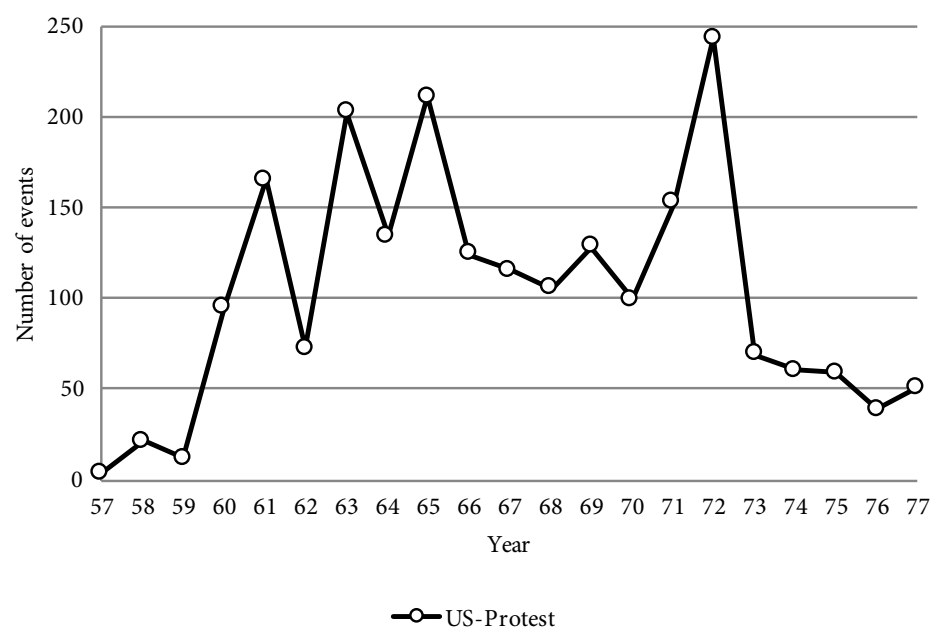

Fig. 1. The number of protest events in the USA $1957^{-1977^{1}}$

A formal analysis of the model shows that these parameters determine the dynamics of the model, which are not always chaotic but may also result in stable equilibria, under certain conditions even in zero-protest. Hence the article explores the relation between the parameter configurations of the model and the resulting conflict dynamics. This analysis is useful for answering the central questions of the article: how to get from a chaotic situation to a stable equilibrium - and from a stable equilibrium to chaos. The first question is of interest for governments, which are generally threatened by chaos, the second for protest movements, which often profit from chaos.

The main model of this article is primarily theoretical with no empirical tests. Consequently the article ends with a discussion why possible checks of the model are difficult. The central problem of testing is not the chaotic nature of the model but rather the lack of specific observational data required for such tests.

\section{A Contagion Model of Social Protest ${ }^{2}$}

This article is based on the trivial wisdom that governments always have opponents who are frustrated by their politics. This share of the frustrated in the total population is as-

1. Data sources: Taylor and Hudson (1976: tab. 3.1), Taylor and Jodice (1983: tab. 2.1).

2. For readers' convenience there is a glossary of mathematical symbols at the end of the article. 
sumed to be equal to $F$ and varies between o and 1. Some of the opponents are so frustrated by their governments that they engage in public protest-demonstrations as postulated by Feierabend and Feierabend (1972) and Gurr (2010: chap. 2). This share of the mobilized in the total population is assumed to be equal to $M$ and generally has as the theoretical lower and upper limits o and 1 . The upper limit of M points to the possibility that more than the share of the frustrated may be mobilized, e.g. by bandwagon-effects finally entailing $\mathrm{M}>\mathrm{F}$. However, as long as $\mathrm{M} \leq \mathrm{F}$, only frustrated citizens are assumed to be the bearers of protest. Consequently, the growth of a protest movement is at the beginning only fueled by frustrated citizens. The related growth-process is assumed to be contagious: non-mobilized frustrated citizens join the protest movement after direct or indirect contact with frustrated protesters. As usual in the theory of innovation diffusion (Hamblin, Jacobsen, Miller, 1973: chap. 4) this is an imitation process, in most cases based on media reporting about protest events (= indirect contact), sometimes, however, also on face-to-face relations (= direct contact). Consequently we hypothesize that the growth of the mobilized citizens

$$
\Delta \mathrm{M}=\mathrm{M}^{\star}(\mathrm{F}-\mathrm{M})
$$

during a finite time interval $\delta>>0$ is proportionate to the product of the shares $\mathrm{M}$ of the mobilized frustrated and $(\mathrm{F}-\mathrm{M})$ of the non-mobilized frustrated. Thus on the one hand, the higher the share of $\mathrm{M}$, the higher the rate of "infection" with protest. On the other hand, the higher the share of the "non-infected" (F - M), the higher the growth of M by new "infections". Both processes together lead to a growth-dynamic, which is logistic and not linear, as described by Hamblin et al. (1973: chap. 4).

Equation (1a) is based on two simplifications, neither of which are realistic: the first assumes that the contagion rate $c$ is always equal 1 and thus need not be mentioned in this equation. This is obviously wrong, since governments try to lower the contagion rate by censorship, and protest movements try to increase it by getting media attention for their political goals and the related protests. Thus equation (1a) has to be generalized as follows:

$$
\Delta \mathrm{M}=\mathrm{c}^{\star} \mathrm{M} *(\mathrm{~F}-\mathrm{M})
$$

This formula obviously includes the special case of equation (1a), as shown by the substitution of $\mathrm{c}$ by 1 . However, in general $\mathrm{c} \neq 1$.

The second simplification of equations (1a) and (1b) implies that there is no governmental repression of protest, which is for authoritarian governments obviously wrong (Gurr, 1972: 20off.). In order to correct this simplification, one has to add to equation (1b) a term $-\left(r^{*} M\right)$, where $r$ is the repression rate. It varies between $o$ and 1 and describes the share of $\mathrm{M}$, which is from one time point to the next demobilized by governmental actions against protesters. Thus by taking repression into account, equation (1b) becomes:

$$
\Delta \mathrm{M}=\mathrm{c}^{\star} \mathrm{M} *(\mathrm{~F}-\mathrm{M})-\mathrm{r}^{\star} \mathrm{M}
$$


In order to assure that $\mathrm{M} \geq \mathrm{o}$ for all possible parameters $\mathrm{c}, \mathrm{F}$, and $\mathrm{r}$, we finally have to introduce into equation (1c) the following safeguard:

$$
\Delta \mathrm{M}=\max \left(\mathrm{c}^{\star} \mathrm{M}^{\star}(\mathrm{F}-\mathrm{M})-\mathrm{r}^{\star} \mathrm{M},-\mathrm{M}\right)
$$

This way $\Delta M \geq-M$, and consequently the next value of $M \geq 0$.

Equation (1d) is the final one, describing the model we analyze in the next section. It is related to the change of protest $\Delta P$ by the following hypothetical proportionality:

$$
\Delta \mathrm{P} \approx \Delta \mathrm{M}
$$

However, although $\Delta \mathrm{P}$ is much easier to observe than $\Delta \mathrm{M}$, we are analyzing in this rather theoretical article mainly equation (1d) or its elementary transformation

$$
\Delta \mathrm{M}=\max \left(-\mathrm{c}^{\star} \mathrm{M}^{2}+\left(\mathrm{c}^{\star} \mathrm{F}-\mathrm{r}\right){ }^{\star} \mathrm{M},-\mathrm{M}\right)
$$

which establishes an inverse parabolic relation between $\mathrm{M}$ and $\Delta \mathrm{M}$.

\section{The Dynamics of the Model}

\subsection{An Overview of the Different Model-Dynamics}

As Dixon (1994: 51) shows, equations (1d) and (3) correspond to a Roos-type logistic growth-model. Their dynamics depend on the weight $\left(c^{\star} \mathrm{F}-\mathrm{r}\right)$ of the linear term of the parabola (3). Five different types of values of $\left(c^{*} F-r\right)$ have to be distinguished (Creedy, Martin, 1994b: 8ff.):

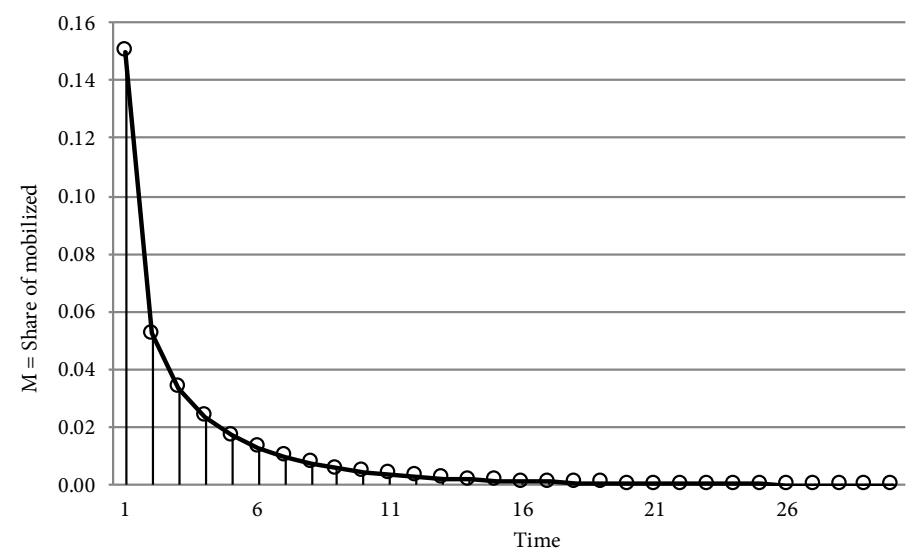

Fig. 2a. Convergence to the stable equilibrium $\mathrm{M}=\mathrm{O}^{3}$

3. Start value of $\mathrm{M}=0.15, \mathrm{~F}=0.0, \mathrm{c}=3.0, \mathrm{r}=0.20, \mathrm{c}^{\star} \mathrm{F}-\mathrm{r}=-0.200$ 
Type 1: $c^{\star} F-r \leq o$ : In this situation the weights of the linear and the quadratic term of equation (3) are negative or zero and consequently yield a negative growth rate $\Delta \mathrm{M}$ such that $\mathrm{M}$ finally reaches the level $\mathrm{M}=0$, where it stabilizes due to the max-clause of equation (3). Fig. 2a illustrates this dynamic, which implies the total demobilization of the protest movement.

Type 2: $o<c^{\star} F-r \leq 2$ : The share $\mathrm{M}$ of mobilized protesters in the total population converges either to the stable equilibrium $\left(c^{\star} \mathrm{F}-\mathrm{r}\right.$ ) / $\mathrm{c}>0$ or alternatively to $\mathrm{o}$, depending on the initial value of M. ${ }^{4}$ The first case is illustrated by Fig. 2 b. The second case, i.e. the convergence of the share $\mathrm{M}$ of the mobilized to $\mathrm{o}$ is in so far a critical event as the protest movement is completely demobilized.

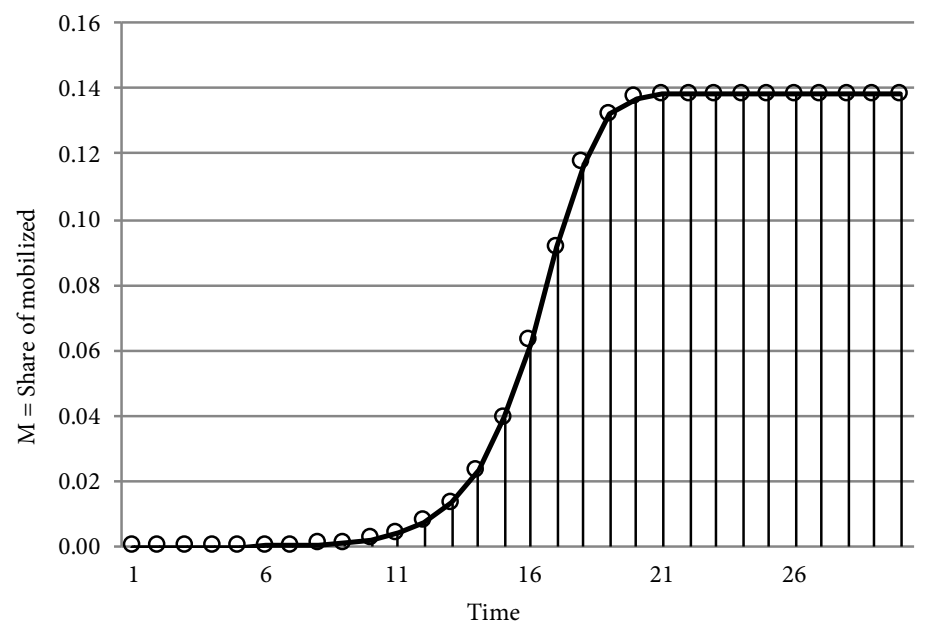

Fig. 2b. Convergence to a stable equilibrium $M \geq 0^{5}$

Type 3: $2<c^{*} F-r \leq 2.57$ : Under the already mentioned assumption that the time interval $\delta$ between two subsequent time points is substantially greater than o (see section 2), the share of the mobilized begins to oscillate in a regular manner. Protesters and government need a finite time interval in order to respond to the political situation. Consequently they "overreact" and tend to miss the stable equilibrium. However, as the illustrative Fig. $2 \mathrm{c}$ shows, government and protesters can easily anticipate the next situation and adapt their strategies accordingly. Obviously, stable oscillations can rarely be observed for a long period of time.

4. If the equilibrium $\Delta \mathrm{M}=0$ is reached and $\left(c^{\star} F-r\right)>0$, formula (3) implies for $M>0$ that $c^{\star} M=$ $\left(c^{*} \mathrm{~F}-\mathrm{r}\right)$. Thus $\mathrm{M}=\left(\mathrm{c}^{*} \mathrm{~F}-\mathrm{r}\right) / \mathrm{c}$ is an equilibrium of $\mathrm{M}$, however only if on the way to this target $\Delta \mathrm{M}$ always satisfies the condition $\Delta \mathrm{M}<-\mathrm{M}$. If this condition is violated, $\mathrm{M}$ is "trapped" at the level o by the max-clause of formula (3) and the equilibrium is $\mathrm{M}=0$. Similarly, if $\left(\mathrm{c}^{*} \mathrm{~F}-\mathrm{r}\right)>0$ and $\mathrm{M}=0$, formula (3) implies that $\Delta \mathrm{M}=\mathrm{O}$ and consequently the equilibrium is $\mathrm{M}=\mathrm{O}$.

5. Start value of $\mathrm{M}=0.00001, \mathrm{~F}=0.25, \mathrm{c}=6.0, \mathrm{r}=0.67, \mathrm{c}^{\star} \mathrm{F}-\mathrm{r}=0.830$. 


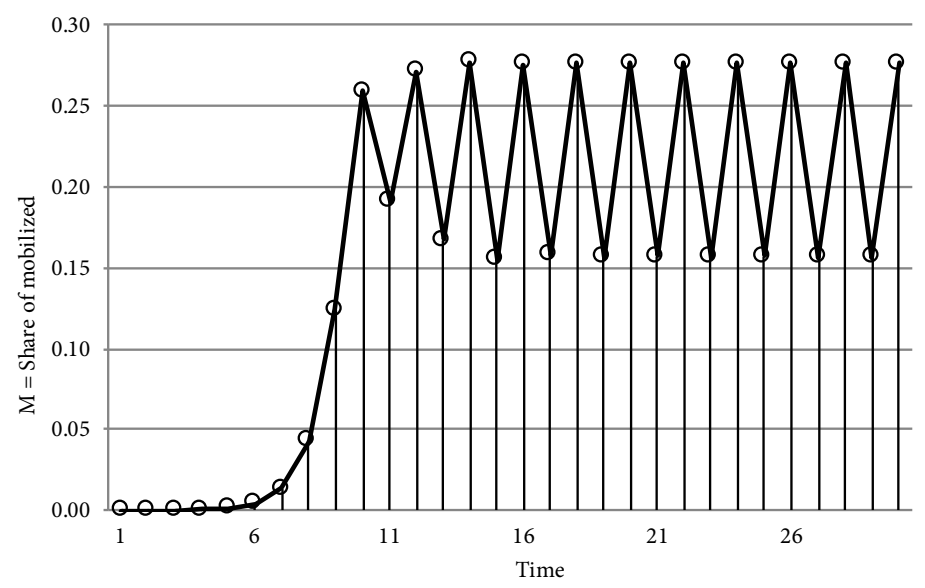

Fig. 2c. Regular oscillations ${ }^{6}$

Type 4: $2.57<c^{*} F-r \leq 3.00$ : For these parameter values deterministic chaos prevails and predictability is lost, as Fig. $2 \mathrm{~d}$ illustrates. Typically for this chaotic situation, even small changes of the initial values of $\mathrm{M}$ may lead to totally different outcomes, which cannot be anticipated. For government, this lack of predictability is critical as it bears the risk of being overwhelmed by a sudden increase in protests, to which there is not enough response by coercive counterforces (see e.g. in Fig. $2 \mathrm{~d}$ the tripling of mobilization between Time $=17$ and Time $=18$ ). For the protest movement this chaos is an opportunity to realize its goals by intimidating or overwhelming the government with violent action. It profits from the opportunity that also non-frustrated citizens may temporarily support the protest movement: for short periods bandwagon-effects tend to increase the size of the protest movement beyond the value $\mathrm{F}$.

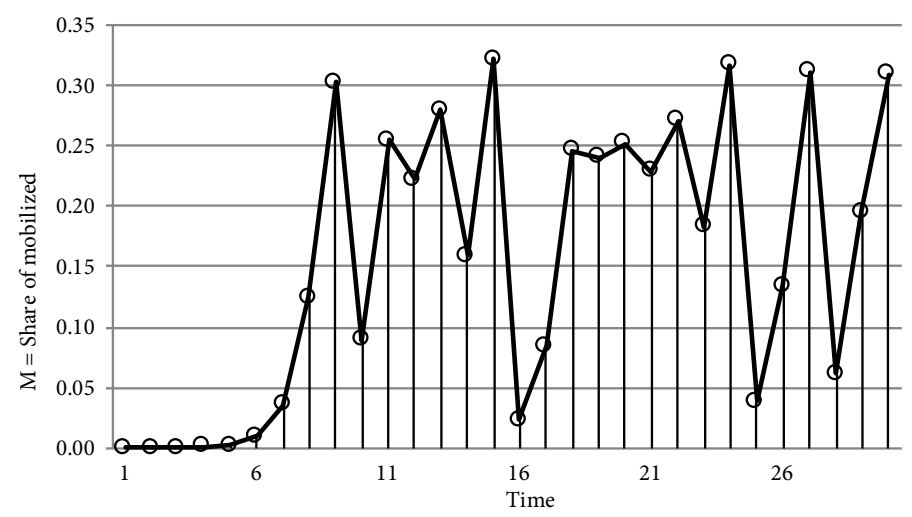

Fig. 2d. Chaos $^{7}$

6. Start value of $\mathrm{M}=0.00001, \mathrm{~F}=0.30, \mathrm{c}=10.0, \mathrm{r}=0.67, \mathrm{c}^{*} \mathrm{~F}-\mathrm{r}=2.330$.

7. Start value of $\mathrm{M}=0.00001, \mathrm{~F}=0.30, \mathrm{c}=12.0, \mathrm{r}=0.67, \mathrm{c}^{*} \mathrm{~F}-\mathrm{r}=2.930$. 
Type 5: $3.00<c^{*} F-r$ : This case implies the transformation of chaos into "hyperchaos", which entails after a very short time the breakdown of one or both conflict parties by driving the share of the mobilized $\mathrm{M}$ either to o or beyond 1. In the first case, the protest movement breaks down due to its total demobilization, which is initiated by non-frustrated and badly motivated citizens and spreads thereafter to the hard core of the frustrated actors. In the second scenario the government is likely to be overwhelmed by a rebellion involving the whole citizenry plus external foreign supporters, such that $M>1$. Since this situation is chaotic, the outcome of hyper-chaos cannot be anticipated. In the exemplary Fig. $2 \mathrm{e}$ the loser is the protest movement that vanishes at Time $=27 \mathrm{after}$ a series of chaotic fluctuations. However, by a small change of the initial value of $M$, the loser in this conflict situation could easily be the government, due to peak values $M>1$. Consequently, the government as well as the protest movement probably avoid the situation $3.00<c^{\star} F-r$.

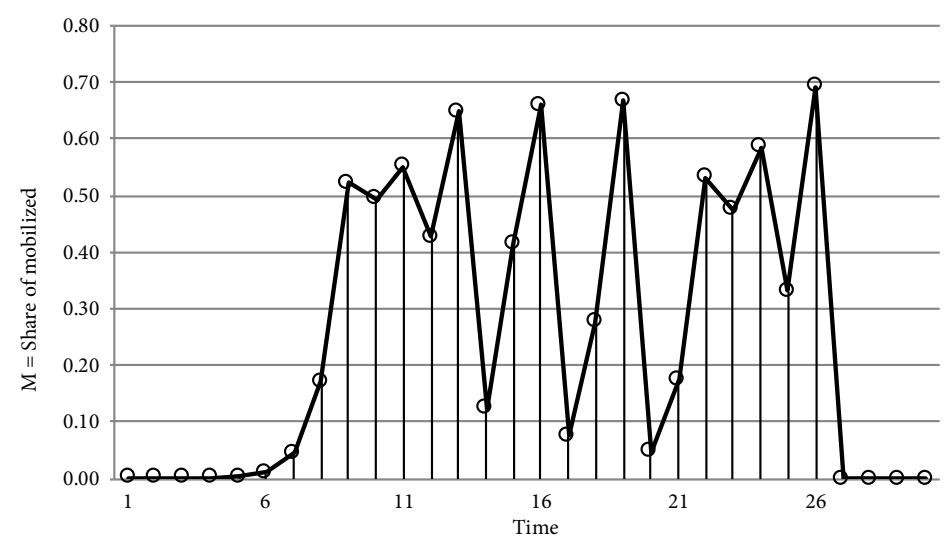

Fig. 2e. Hyper-chaos ${ }^{8}$

Figs. 2a-e represent ideal types of conflict dynamics with constant parameters $c, r$, and $\mathrm{F}$. This is not realistic as governments and protest movements try to change these parameters in order to pursue their goals (see section 3.3). Apart from such strategic actions there may be societal developments like e.g. the spread of the internet, which can lead to the destabilization of formerly constant parameter values like the contagion rate $c$. In order to model such changes the author proposes the segmentation of the simulated social history of a country into sequences of distinct periods with internally stable parameter values, which may also result in changes from one type of conflict dynamics to another. Fig. 3 illustrates such a change caused by an increase of the level of frustration from $\mathrm{F}=0.15$ to $\mathrm{F}=0.30$ at Time $=21$. This increase of $\mathrm{F}$, e.g. produced by a rise of food-

8. Start value of $\mathrm{M}=0.00001, \mathrm{~F}=0.625, \mathrm{c}=6.0, \mathrm{r}=0.67, \mathrm{c}^{\star} \mathrm{F}-\mathrm{r}=3.077$. 
prices, triggers in Fig. 3 the transition from a stable equilibrium with a relatively low level of mobilization $\mathrm{M}$ to chaos with a higher average level of conflict.

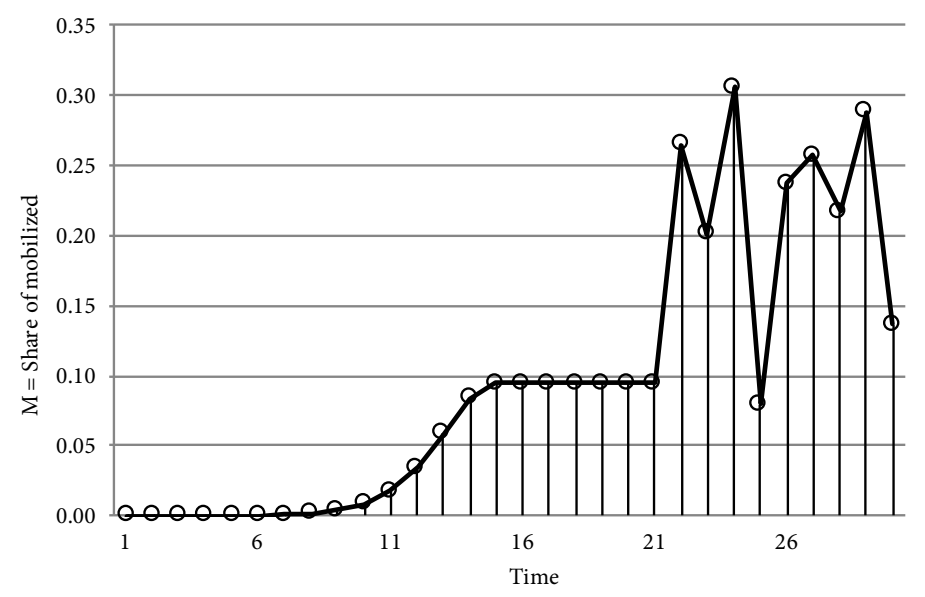

Fig. 3. The transition from equilibrium to chaos due to an increase of frustration from $\mathrm{F}=0.15$ to $\mathrm{F}=0.30$ at Time $=21^{9}$

\subsection{The Relation Between Parameter Values and Model Dynamics}

This section aims at localizing the different model dynamics of section 3.1 in a parameter space defined by r, F, and c. For this purpose we have to analyze the frontiers between the following types of dynamics:

a) Convergence to the stable equilibrium $\mathrm{M}=0$, representing the perfect demobilization of the protest movement.

b) Convergence to a stable equilibrium $\mathrm{M} \geq 0$, which may be at $\mathrm{M}=\left(\mathrm{c}^{\star} \mathrm{F}-\mathrm{r}\right) / \mathrm{c}$ or alternatively at $\mathrm{M}=\mathrm{O}$.

c) Stable oscillations.

d) Chaos.

e) Hyper-chaos.

According to section 3.1, the frontiers between these types of dynamics are located as follows:

between (a) and (b), which separates the zones called Equi $=o$ and Equi $\geq o$ at $^{10}$

$$
\mathrm{F}=(\mathrm{r}+\mathrm{o}) / \mathrm{c}
$$

9. Start value of $\mathrm{M}=0.00001$. Values for $\mathrm{t} \leq 2 \mathrm{O}: \mathrm{F}=0.15, \mathrm{c}=12.0, \mathrm{r}=0.67$. Values for $\mathrm{t} \geq 21: \mathrm{F}=0.30, \mathrm{c}=$ 12.0, $\mathrm{r}=0.67$.

10. From $c^{\star} F-r \leq o$ required for a stable equilibrium at level $M=o$ (see section 3.1) follows $F=(r+o) / c$. 
between (b) and (c), which separates the zones called Equi $\geq 0$ and Osci at ${ }^{11}$

$$
\mathrm{F}=(\mathrm{r}+2.0) / \mathrm{c}
$$

between (c) and (d), which separates the zones called Osci. and Chaos at ${ }^{12}$

$$
\mathrm{F}=(\mathrm{r}+2.57) / \mathrm{c}
$$

between (d) and (e), which separates the zones called Chaos and Hyper Ch. at ${ }^{13}$

$$
\mathrm{F}=(\mathrm{r}+3.0) / \mathrm{c}
$$

Figs. $4 \mathrm{a}-\mathrm{d}$ visualize the resulting parameter space, which suggests the following conclusions:

- Chaos is an early warning sign of an immanent breakdown into hyper-chaos, which may concern the government as well as the protest movement: a small increase in contagion $\mathrm{c}$ or frustration $\mathrm{F}$ or a small decrease in repression $\mathrm{r}$ leads from chaos to hyper-chaos and triggers such a breakdown. Similarly, regular oscillations are an early warning indicator of chaos.

- As Figs $4 \mathrm{a}-\mathrm{d}$ demonstrate, protest mobilization leading to $\mathrm{M}>0$ always requires a minimum level of frustration $\mathrm{F}>0$. This threshold of frustration increases with repression $r$ and decreases with contagion $c$. For contagion $c=0$ even the highest level of $\mathrm{F}$ is not sufficient for triggering a mobilization $\mathrm{M}>0$, if the repression $\mathrm{r}>0$.

- Figs $4 \mathrm{a}-\mathrm{d}$ show for chaos and hyper-chaos regularities similar to protest mobilization: on the one hand, the higher the repression $\mathrm{r}$, the more frustration $\mathrm{F}$ is needed in order to trigger chaos or hyper-chaos. On the other hand, the lower the contagion $\mathrm{c}$, the more frustration $\mathrm{F}$ is needed to trigger these dynamics.

\subsection{Implications for Getting in and out of Chaos}

Chaos is dangerous to governments for two reasons. On the one hand, it implies sudden and unpredictable outbreaks of protest, which may be strong enough to overthrow the government. On the other hand, its dynamics are sometimes hard to distinguish from the initial fluctuations of the extremely detrimental hyper-chaos. Consequently a rational government with a minimum level of risk-aversion should try to get out of chaos, either to a stable equilibrium Equi $\geq 0$ at any level of mobilization or to the total demobilization of protest represented by the zone Equi $=$ o. Since the former equilibrium often means a stable level of residual conflict, it may be used for legitimizing the maintenance of authoritarian rule that prevents society from slipping back into chaos. For reaching these

11. From $\mathrm{o}<\mathrm{c}^{*} \mathrm{~F}-\mathrm{r} \leq 2$ required for a stable equilibrium at level $\mathrm{M} \geq \mathrm{o}$ (see section 3.1 ) follows $\mathrm{F}=$ $(\mathrm{r}+2) / \mathrm{c}$.

12. From $2<c^{\star} F-r \leq 2.57$ required for stable oscillations (see section 3.1) follows $\mathrm{F}=(\mathrm{r}+2.57) / \mathrm{c}$.

13. From $2.57<c^{\star} F-r \leq 3$ required for chaos (see section 3.1) follows $F=(r+3) / c$. 
equilibria, government may increase the repression rate $\mathrm{r}$, reduce the frustration $\mathrm{F}$ by political or economic reforms, or decrease the contagion rate $\mathrm{c}$ by censoring the media (see Figs $4 \mathrm{a}-\mathrm{d}$ ). The required effort for leaving the zone of chaos depends on whether the goal is total demobilization (Equi $=0$ ) or stabilization (Equi $\geq 0$ ) of protest: in terms of the changes of the parameters $r, c$, and F, the first goal is obviously more demanding than the second.

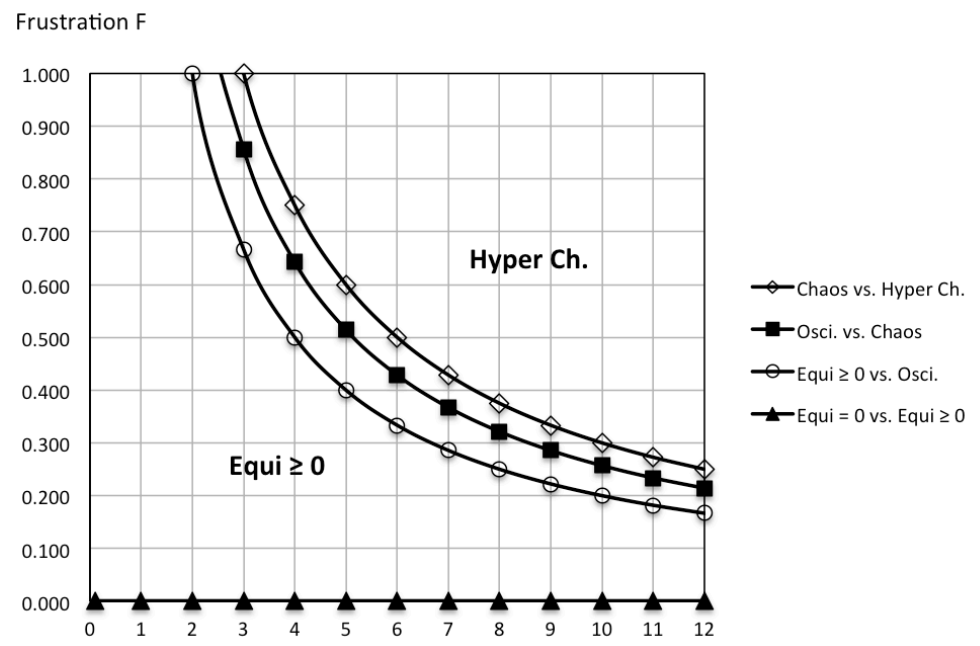

Fig. 4a. The frontiers between different conflict dynamics for repression $r=0.00^{14}$

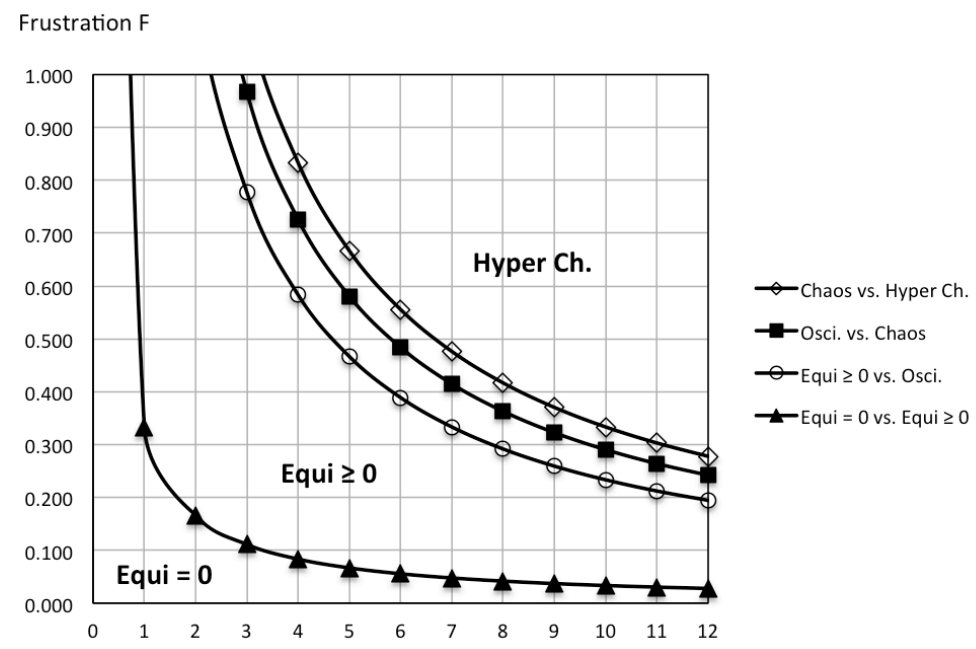

Fig. 4b. The frontiers between different conflict dynamics for repression $r=0.33$

14. Legend to Figs $4 a-d$ : Equi $=0$ : Convergence to equilibrium $M=0$; Equi $\geq 0$ : Convergence to equilibrium $\mathrm{M} \geq 0$ (see Fig. 2a); Osci: Stable oscillations (see Fig. 2c); Chaos: Chaos (see Fig. 2d); Hyper Ch.: Hyperchaos (see Fig. 2e). 


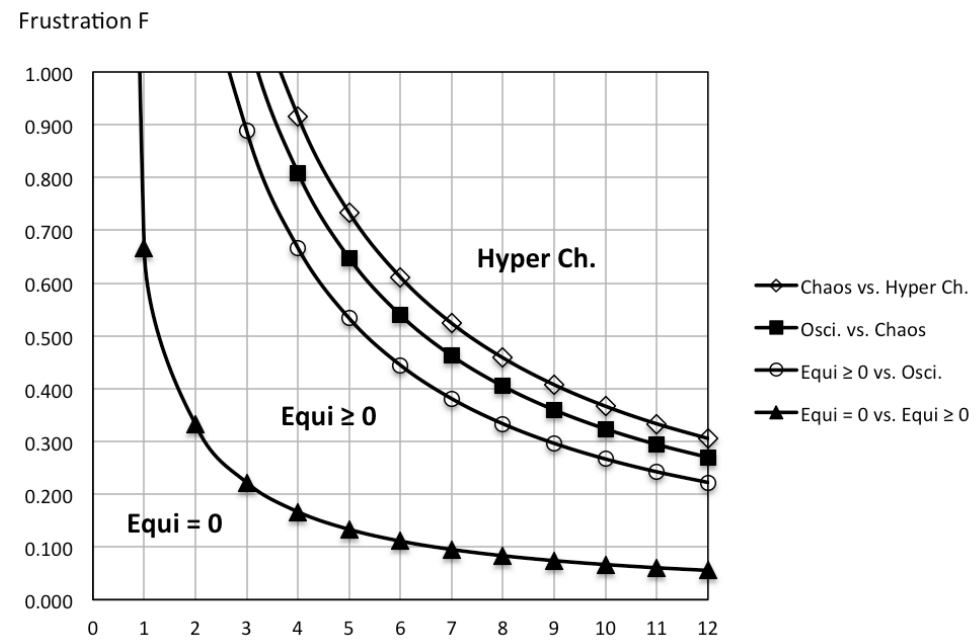

Fig. 4c. The frontiers between different conflict dynamics for repression $r=0.67$

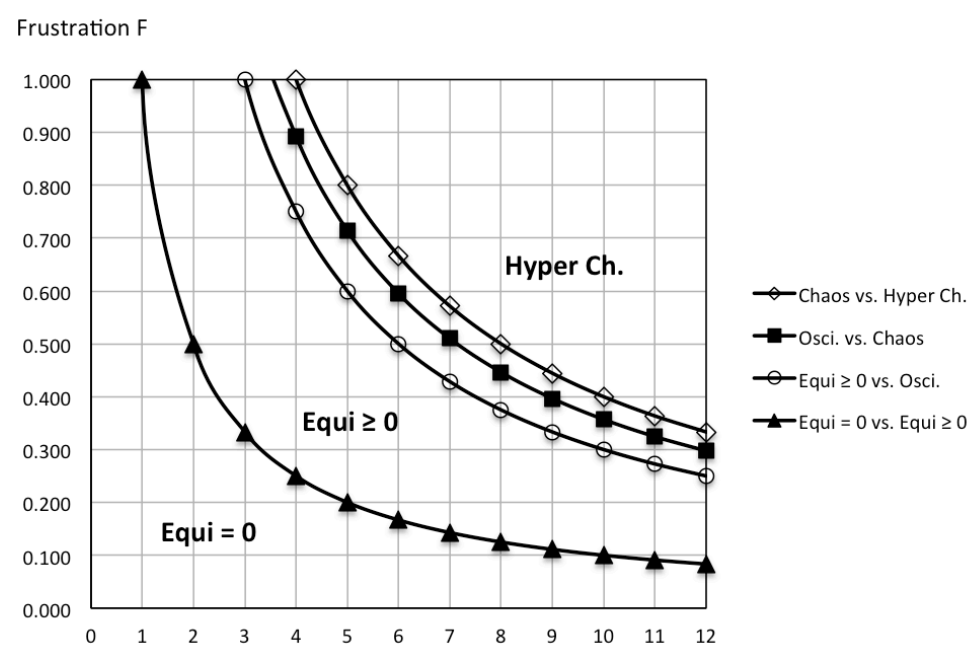

Fig. 4 d. The frontiers between different conflict dynamics for repression $r=1.00$

According to Figs $4 \mathrm{a}-\mathrm{d}$ it is always possible to reach from chaos either Equi $\geq 0$ or Equi $=o$ by reducing the share $F$ of the frustrated. A comparison of the different values of $\mathrm{c}$ and $\mathrm{r}$ in Figs $4 \mathrm{a}-\mathrm{d}$ makes clear that the lower the contagion $\mathrm{c}$ and the higher the repression $\mathrm{r}$, the higher the frustration $\mathrm{F}$, for which these goals are still attainable. In the case of $r=0$ (see Fig. 4a) the necessary lowering of $F$ for reaching Equi $=0$ is always total, which obviously implies very substantial reforms. This is in sharp contrast to Fig. $4 \mathrm{~d}$, where for the highest level of repression $r=1$ and a contagion $c=4$ the frustration has e.g. only to be lowered to $\mathrm{F}=0.25$ in order to get from chaos to Equi $=0$. 
The increase of the repression $r$ is a less successful strategy than the previously discussed decrease of the frustration F. A comparison of Figs $4 \mathrm{a}-\mathrm{d}$ shows that the frontiers between oscillations and chaos on the one hand and chaos and hyper-chaos on the other are not much influenced by the value of $r$. Consequently there are chaotic situations like the one for $\mathrm{r}=\mathrm{o}, \mathrm{c}=5$, and $\mathrm{F}=0.600$, where an increase of the repression $\mathrm{r}$ even by the considerable amount of 0.33 units is not sufficient for getting out of chaos (cf. Fig. $4 \mathrm{a}$ vs. Fig. 4b).

In contrast, the reduction of the contagion rate $c$ is a successful way for getting out of chaos. Reaching Equi $\geq 0$ of protest-stabilization is always relatively easy. The equilibrium zone Equi $=\mathrm{o}$ of total demobilization is, however, only reachable if the contagion rate $\mathrm{c}$ is substantially reduced by ca. $75 \%$ and if the repression $r>0$. In internet societies, where people can easily access foreign uncensored media, this change may be unrealistic. Moreover, the contagion rate is also influenced by protest movements, which are generally interested in increasing the value of $\mathrm{c}$ by additional media reports about protest events, such that others are induced to support their concerns. The parameter $\mathrm{c}$ is the only instrument, to which they have access in order to provoke a chaotic situation, which is generally in their interest. However, the use of $\mathrm{c}$ by protest movements is for this purpose only possible if the frustration has reached a minimal threshold. For $r=0$ an increase of the contagion rate to $c=12$ requires a frustration $F>0.2$ to trigger chaos (see Fig. 4 a), whereas for $r=1$ the corresponding threshold of frustration is even higher, i.e. $F>0.3$ (see Fig. 4d). Thus governments wanting to make the contagion parameter $c$ unusable for protest movements should engage in reforms, which drive the frustration $\mathrm{F}$ below the mentioned critical thresholds.

\section{Summary and Outlook}

This article presents a logistic model of protest-contagion, which describes the following types of conflict dynamics: hyper-chaos, chaos, regular oscillations, and convergence to a stable equilibrium, which can include zero-protest. By purposive changes of the model parameters it is possible to get from a conflict dynamic to another, e.g. from chaos to a zero-protest equilibrium. Especially efficient according to the analyses of the previous section is the reduction of the frustration $\mathrm{F}$ by reforms, which often leads to a change from an old chaotic to new conflict-free order. Likewise, but beyond the control of the political actors, the dynamics of hyper-chaos may trigger the sudden replacement of the old regime by a new one or the breakdown of the protest movement. 


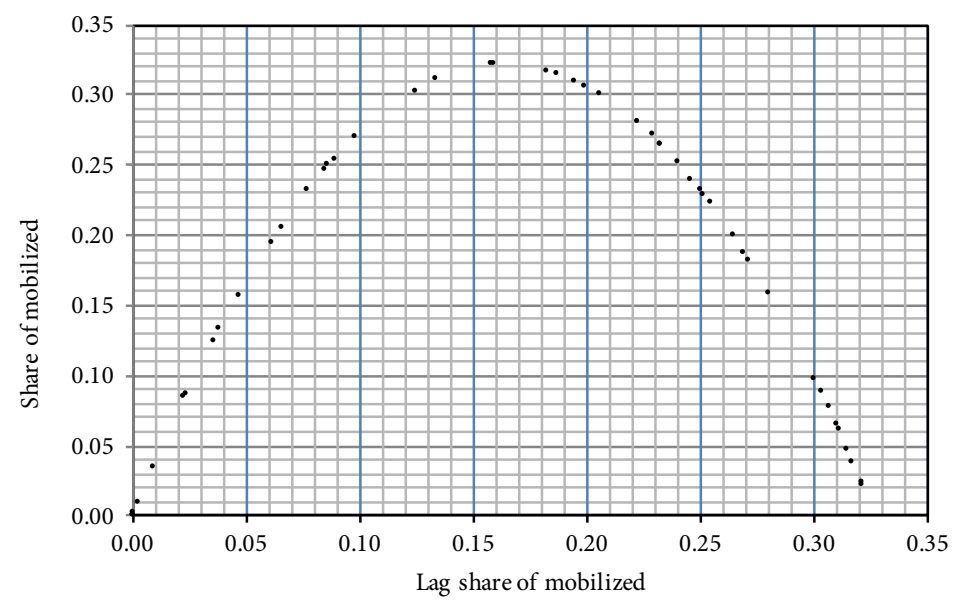

Fig. 5. Phase diagram of the chaos dynamics of Fig. $2 d^{15}$

Insights into these changes were gained by a formal analysis of a model, which is theoretically plausible but empirically untested. This deficiency calls for systematic empirical checks in follow-up studies, which are, however, not easy to realize. One of the obstacles seems to be the chaotic nature of the model, which is nonetheless easy to solve. Since the observed $\Delta \mathrm{M}$ are generally sufficiently large such that $\Delta \mathrm{M}>-\mathrm{M}$, the relation between the past mobilization $M_{-}$and the current mobilization $\mathrm{M}$ is a perfectly deterministic inverse parabola $^{16}$

$$
\mathrm{M}=-\mathrm{c}^{\star} \mathrm{M}_{-}{ }^{2}+\left(\mathrm{c}^{\star} \mathrm{F}+1-\mathrm{r}\right){ }^{\star} \mathrm{M}_{-}
$$

exemplified by Fig. 5, which is just another view of the chaos-dynamics of Fig. 2 d. This parabola of deterministic chaos is different from the phase diagram of stochastic chaos, where the whole (M-,M)-space would be filled with data-points (Liebovitch, 1998: 127). Thus by using the level of protest $\mathrm{P}$ as a substitute for $\mathrm{M}$ (see proportionality (2)) it is possible to estimate the parameters $-c$ and $\left(c^{\star} F+1-r\right)$ of equation (5) by means of multiple linear regressions (Cramer, Howitt, 2004: 139) ${ }^{17}$ However, as a first real problem, it is evident that these two estimates are not sufficient for determining the elementary parameters $\mathrm{F}$ and $\mathrm{r} ;-\mathrm{c}$ and $\left(\mathrm{c}^{*} \mathrm{~F}+1-\mathrm{r}\right)$ can at best be used for a general test of the model, which checks the correspondence between the expected and observed values of $\mathrm{M}$. Moreover, the parameters of the model are assumed to change over time. Consequently one has to identify periods in the political history of a country with relatively stable pa-

15. Model parameters: Start value of $\mathrm{M}=0.00001, \mathrm{~F}=0.30, \mathrm{c}=12.0, \mathrm{r}=0.67, \mathrm{c}^{\star} \mathrm{F}-\mathrm{r}=2.930$.

16. If $\Delta \mathrm{M}>-\mathrm{M}$, equation (3) implies: $\mathrm{M}=\mathrm{M}_{-}+\Delta \mathrm{M}=\mathrm{M}_{-}-\mathrm{c}^{\star} \mathrm{M}_{-}{ }^{2}+\left(\mathrm{c}^{\star} \mathrm{F}-\mathrm{r}\right){ }^{\star} \mathrm{M}_{-}=-\mathrm{c}^{\star} \mathrm{M}_{-}{ }^{2}+$ $\left(c^{*} \mathrm{~F}+1-\mathrm{r}\right){ }^{\star} \mathrm{M}_{-}$.

17. $-\mathrm{c}$ and $\left(\mathrm{c}^{*} \mathrm{~F}+1-\mathrm{r}\right)$ are just the coefficients of a regression equation with two explanatory variables $\mathrm{M}_{-}{ }^{2}$ and $\mathrm{M}_{-}$. This facilitates their estimation by multiple linear regressions. 
rameter values, which requires good country-specific knowledge. Plausible events that mark the beginning or end of such periods are democratic electoral swings, major public policy changes such as the introduction of censorship, or economic crises, which increase the level of frustration. The "proof" that a historical period has correctly been identified is the correspondence between the simulated and observed conflicts in this period. If needed, the period may be shortened or extended by statistical experimentation. Finally, testing and parameter estimation require time series with an appropriate time interval $\delta$ (Liebovitch, 1998: 212). This parameter is probably much shorter than the 1 year-grid data available in many conflict statistics as Taylor and Hudson (1976: tab. 3.1) and Taylor and Jodice (1983: tab. 2.1). So the main challenge of model testing and parameter estimation is access to appropriate data.

\section{Glossary of Mathematical Symbols}

c: Contagion rate, where $\mathrm{o} \leq \mathrm{c}$.

$\delta$ : Time interval between two subsequent values $\mathrm{M}$, where $\delta>0$.

F: Share of the politically frustrated population, where $\mathrm{o} \leq \mathrm{F} \leq 1$.

M: Share of the population mobilized for protest.

M-: $M$ lagged by the time interval $\delta$.

$\Delta \mathrm{M}$ : Growth of $\mathrm{M}$ during a finite time interval $\delta>>0$.

$\mathrm{r}$ : Repression rate, where $\mathrm{o} \leq \mathrm{r} \leq 1$.

P: Number of protest events in the analyzed country.

$\Delta \mathrm{P}$ : Growth of $\mathrm{P}$ during a finite time interval $\delta>>0$.

$\approx$ : Proportionality between two variables.

\section{References}

Brown C. (1995) Chaos and Catastrophe Theories, Thousand Oaks: SAGE.

Bühl W. (1990) Sozialer Wandel im Ungleichgewicht: Zyklen, Fluktuationen, Katastrophen, Stuttgart: Ferdinand Enke.

Cramer D., Howitt D. (2004) The SAGE Dictionary of Statistics, London: SAGE.

Creedy J., Martin V. (eds.) (1994a) Chaos and Non-Linear Models in Economics: Theory and Applications, Aldershot: Edward Elgar.

Creedy J., Martin V. (1994b) The Strange Attraction of Chaos in Economics. Chaos and Non-Linear Models in Economics: Theory and Applications (eds. J. Creedy, V. Martin), Aldershot: Edward Elgar, pp. 7-29.

Dixon R. (1994) The Logistic Family of Discrete Dynamic Models. Chaos and Non-Linear Models in Economics: Theory and Applications (eds. J. Creedy, V. Martin), Aldershot: Edward Elgar, pp. 44-69.

Eve R., Horsfall S., Lee M. E. (eds.) (1997) Chaos, Complexity, and Sociology: Myths, Models, and Theories, Thousand Oaks: SAGE. 
Feierabend I. K., Feierabend R. L. (1972) Systemic Conditions of Political Aggression: An Application of Frustration-Aggression Theory. Anger, Violence, and Politics: Theories and Research (eds. I. K. Feierabend, R. L. Feierabend, T. R. Gurr), Englewood Cliffs: Prentice-Hall, pp. 136-183.

Gurr T. R. (1972) A Causal Model of Civil Strife: A Comparative Analysis Using New Indices. Anger, Violence, and Politics: Theories and Research (eds. I. K. Feierabend, R. L. Feierabend, T. R. Gurr), Englewood Cliffs: Prentice-Hall, pp. 184-222.

Gurr T. R. (2010 [1970]) Why Men Rebel, Bolder: Paradigm.

Hamblin R. L., Jacobsen R. B., Miller J. L. L. (1973) A Mathematical Theory of Social Change, New York: John Wiley.

Kiel D., Elliott E. (eds.) (1996) Chaos Theory in the Social Sciences: Foundations and Applications, Ann Arbor: University of Michigan Press.

Liebovitch L. (1998) Fractals and Chaos Simplified for the Life Sciences, Oxford: Oxford University Press.

Taylor Ch., Hudson, M. (1976) World Handbook of Political and Social Indicators (2nd edition), New Haven: Yale University Press.

Taylor Ch., Jodice, D. (1983) World Handbook of Political and Social Indicators, Vol. 2 (3rd edition), New Haven: Yale University Press.

\title{
Возникновение порядка из хаоса: математическая модель политического конфликта
}

\author{
Георг П. Мюллер \\ Факультет экономии и социальных наук, Фрибурский университет \\ Адрес: Blvd de Pérolles 90, CH-1700 Fribourg, Switzerland \\ E-mail: georg.mueller_unifr@bluewin.ch
}

Данные динамики насильственных конфликтов внутри стран, протестов или беспорядков, зачастую демонстрируют нерегулярные флуктуации. В статье доказывается, что эти флуктуации являются проявлением детерминированного хаоса, который можно описать через относительно простое дифференциальное уравнение. В основе уравнения лежит модель последействия, которая описывает взаимодействие трех групп: а) уже мобилизованные восставшие граждане, протестующие против правительства и его политики, б) группы фрустрированных граждан, которые не присоединились к протестам в самом начале, в) репрессивные правительственные силы, которые стремятся обуздать протесты и сократить число участвующих в беспорядках граждан. Интеграция этих процессов приводит к модели логистического роста, которая сходится при множестве конфигураций параметров и ведет к стабилизации доли протестующих, в том числе на нулевом уровне в некоторых ситуациях. Однако при других параметрах эта модель может привести к хаотическим флуктуачиям в протестных действиях, которые опасны для правящего режима, поскольку являются непредсказуемыми и носят массовый характер. При помощи компьютерного моделирования в статье анализируются последствия различных параметрических конфигураций для протестной динамики. Ради политического выживания 
многие правительства заинтересованы в том, чтобы выйти из динамики хаотичного конфликта и перейти к состоянию стабильного равновесия протеста, а затем свести его на нулевой уровень. Они могут добиться этого при помощи 1) реформ, которые сократят долю фрустрированных граждан, потенциально способных на протест, 2) устрашения протестующих и/или репрессий, 3) введения цензуры в сообщениях СМИ о протесте для ограничения распространения информации о протесте. Формальный анализ модели показывает, что наиболее успешными оказываются реформы, которые сокращают долю фрустрированных граждан и, как следствие, ведут к новому политическому порядку.

Ключевые слова: модель последействия, политический конфликт, реформы, теория хаоса, математические модели, компьютерная симуляция 